\title{
The Effect of E-mailing on Vocabulary Retention of Iranian Lower Intermediate EFL Learners
}

\author{
Mansoor Fahim \\ Allameh Tabataba'i University, Tehran, Iran \\ Email: dr.mfahim@yahoo.com \\ Khalil Motallebzadeh \\ Islamic Azad University, Torbat-e-Heidareih Branch, Iran \\ Email: k.motalleb@iautorbat.ac.ir, kmotallebz@gmail.com \\ Zeinab Sazegar \\ Islamic Azad University, Garmsar Branch, Tehran, Iran \\ Email: zeynab-sa@yahoo.com
}

\begin{abstract}
Technologies have been enhancing education all the time and new technologies have always been utilized firstly by education, especially with the emergence of computer related information technology (Devedzic, 2000). E-learning provides faster and greater access to information for education (Hamilton et al., 2001). Online training also creates a personalized learning experience and reduces costs. In addition, e-learning is ideal for global corporations with people in multiple time zones, there is no need to coordinate travel and delivery schedules. Electronic mail (e-mail) is an asynchronous medium, which allows participants to control their own timetables and fit learning around their other commitments. The present study aimed to examine the effect of e-mailing on vocabulary retention of Iranian EFL learners. Forty participants were assigned into experimental and control groups. The participants received English words as well as definitions and example sentences either on paper or through e-mail messages in a spaced and scheduled pattern of delivery three times a week throughout 10 sessions. Students' statues in retention of vocabulary were compared at the end of the study. The obtained results showed that the use of e-mail technology can enhance the retention of vocabulary. This study also provides pedagogical implications for utilizing e-mail as an effective and flexible learning tool.
\end{abstract}

Index Terms - e-learning, vocabulary retention, e-mail, EFL

\section{INTRODUCTION}

Education has not remained inflexible towards the profound changes taking place in other areas of knowledge. The impact of those changes on the educational area is increasingly evident. New technologies are producing changes in the traditional pedagogical models. They have broadened the array of possibilities for the limited traditional teaching-learning process in which the teacher is the only source of knowledge, the chalk and board are the best didactic aids and the classroom is the only place where this process can be appropriately carried out (Rey \& Rosado, 2001, p.12).

Hambrecht and Company (2000) suggest that electronic education is effective because it "offers collaboration and interaction with experts and peers as well as a higher success rate than alternatives" (p.10). Electronic learning provides faster and greater access to information for education (Hamilton et al., 2001, cited in Maynard \& Cheyne, 2005). However, consideration should be given to the implications of taking on this e-learning initiative, including financial support, staff workload and changing roles (Wilson, 2003, p.7). Camenson (2007, p.2) also stated that EFL students only spend a few hours per week studying English, have little exposure to English outside the classroom, have little opportunity to practise their newly-acquired language skills, and have a native language background in the classroom. There are only 4 hours per week for the English classes in most Language institutes and schools. Teachers must make difficult choices about how to use that limited time to promote language learning and there is an urgent need for them to find an effective self-study approach for students to enlarge their vocabulary size. "Because of the class time constraint, vocabulary reinforcement and study is frequently the responsibility of the student outside the classroom" (Grace, 1998, p.8).

\section{REVIEW OF LITERATURE}

A. Basics of E-learning 
Schank (2002), Roffe (2002), Sambrook (2003) and Tsai \& Machado (2002) refer to e-learning as "communication and learning activities through computers and networks (or via electronic means)". To be more specific, Fry (2000) defines e-learning as "delivery of training and education via networked interactivity and a range of other knowledge collection and distribution technologies."Wild, Griggs and Downing (2002) also had the same definition as Fry's - they defined e-learning as the creation and delivery of knowledge via online services in the form of information, communication, education and training. Bleimann (2004) stated that e-learning is a self-directed learning that is based on technology, especially web-based technology. He also stressed that e-learning is collaborative learning.

Internet and web technology is important in e-learning; Horton (2001) defines e-learning as "the use of Internet and digital technologies to create experience that educate fellow human beings." Apart from web-based technology, e-learning seemed to require multimedia based courseware (Evans \& Fan, 2002; Lahn, 2004). Therefore, it is clear that e-learning is centered on Information and Communication Technology (ICT). It is not surprising that Hamid (2002) and Lytras, Pouloudi and Poulymenakou (2002) mentioned that e-learning evolved around Information Technology to enhance the learning performance and efficiency. Furthermore, Evans \& Hasse (2001) pointed out that technology is indeed needed in e-learning to educate the learner through the usage of two-way video, two-way computer interaction, cable, satellite downlinks and Internet. Honey (2001) provided many good examples of learning activities that involved ICT. These examples include learning from e-mail, online research, online discussion and coaching by e-mail. From these definitions and examples, we can therefore define e-learning as learning activities that involve computers, networks and multimedia technologies.

Research about e-learning as part of a blended approach to learning, which appears to hold significant promise, would be particularly beneficial. "Additional research will allow academicians and practitioners to make better decisions about where e-learning can be applied most effectively, how, and under what circumstances" (Cappel \& Hayen, 2004, pp. 55-56).

\section{B. Electronic Mail as a Learning Tool}

Electronic mail is communication on internet by personal computer, mobile phone or other tools. Content of e-mail presents through any kinds of form; message, picture, photo or video clip. Electronic mail is a method of exchanging digital messages. E-mail systems are based on a store-and-forward model in which e-mail computer server systems accept, forward, deliver and store messages on behalf of users, who only need to connect to the e-mail infrastructure, typically an e-mail server, with a network-enabled device for the duration of message submission or retrieval. An electronic mail message consists of two components, the message header, and the message body, which is the e-mail's content. The message header contains control information, including, minimally, an originator's email address and one or more recipient addresses (Wikipedia, 2010).

How to use e-mail in the classroom is the focus of the paper by Nagel (1999, p.87) "E-mail in the virtual ESL/EFL Classroom." It deals with more advanced issues connected with the use of e-mail in teaching, and especially with how to be most effective and to get optimal results in the use of e-mail as an instructional tool. This paper tries to achieve these goals by illustrating the difference between e-mail and academic writing, considering how e-mail functions as a learning tool, and whether to use a listserv or not. It also addresses a number of other problems painful for a wired classroom, trying to propose some workable solutions to them.

\section{Teaching and Learning Vocabulary}

Vocabulary is basic to communication and often seen as the greatest source of problems by second language learners. "When students travel, they don't carry grammar books, they carry dictionaries" (Krashen, as cited in Lewis, 1993, p.iii)). Today's language teachers and researchers have realized the important role of vocabulary in different pedagogical tasks. There is no doubt that virtually all L2 learners and their teachers are well aware of the fact that learning a L2 involves the learning of large numbers of words (Avila\& Sadoski, 1996; Laufer \& Hulstijn, 2001).

Norbert Schmitt (1997, p.18) believed that "In the last 20 or so years, there has been a growing realization that total language proficiency consists of much more than just grammatical competence.'In vocabulary teaching, teachers can apply a host of strategies and activities. According to Hatch and Brown (2000, p.401), teaching strategies refer to everything teachers do or should do in order to help their learners learn.

\section{L2 Vocabulary Acquisition}

One way to study the task of vocabulary learning/acquisition is through the distinction between knowing a word and using a word. In operational terms, knowing a word may be seen as a continuum ranging from blurry recognition of its spelling or auditory pattern to (semantically, syntactically, stylistically) correct and contextually appropriate productive use. Retrieval of a word from the mental lexicon for productive use requires a higher degree of accessibility or, in other words, a more solid integration in various networks than is needed for receptive use (Groot, 2000, p.76). In other words, the purpose of vocabulary learning should include both recalling words and the ability to apply them automatically in a wide range of language contexts when the need arises. Vocabulary learning strategies, therefore, have to incorporate strategies for recognizing and knowing as well as using words. Another way to view vocabulary learning is to take it as a process of interconnected sub-tasks. When learners first encounter a new word, they might guess its meaning and usage from accessible tokens. Some learners might resort to consulting a dictionary. Others might make notes in the 
margins, between lines, or in a separate vocabulary notebook. Some learners will take advantage of simple rote repetition to commit the word to memory. Some would even attempt to use the word enthusiastically in a real context. Each of these task stages demands metacognitive decision, choice, and deployment of cognitive strategies for vocabulary learning. (Groot, 2000).Finally, by using vocabulary cards and negotiating vocabulary meaning, learners can become more autonomous and can actively take charge of enlarging their vocabulary. Ultimately, "it is the learners who are responsible for implementing techniques presented by teachers, regularly reviewing target lexis, and monitoring their own learning" (Hunt \& Beglar, 2005).

Regarding the aforementioned literature, the researcher is aimed to investigate the effect of e-mailing on vocabulary retention of Iranian lower intermediate EFL learners. The following research question and null hypothesis will be answered in this research:

Research Question: does e-mail have any effect on vocabulary retention of Iranian lower-intermediate EFL learners?

Null hypothesis: e-mail does not have any significant effect on vocabulary retention of Iranian lower-intermediate EFL learners.

\section{METHODOLOGY}

\section{A. Participants}

To answer the research question, 40 female lower- intermediate EFL learners, ranging in age from 16 to 23 , learning English at Khorasan English Language School, Mashhad, Iran took part in the study. In order to homogenize the participants and to make sure about their level of general proficiency, a Nelson test (version 4,150 C) was administered to the participants. After analyzing the data, participants were selected and randomly assigned into 20 participants experimental and 20 participants control groups.

\section{B. Instrumentation}

For the purposes of the present study, three instruments were utilized:

(1) Nelson Test of Proficiency was administered to a group of 50 lower-intermediate EFL learners to homogenize the participants based on their language proficiency level. The researcher administered this test at Khorasan English Institute in Mashhad. The reliability index of this test was estimated through Kuder-Richarson formula 21 as 0.82.

(2) As the aim of this study is to examine the effect of e-mailing on vocabulary retention, a pre-test including vocabulary was developed (researcher-made pre-test). The source for making the pre-test was a lower intermediate book entitled 'Thoughts and Notions' (by Ackert \& Lee, 2005). This researcher-made test was piloted on the same level participants in another English Language Institute. Having analyzed the data, the result showed that the reliability calculated through Kuder-Richarson formula 21 was 0.87 . Then, the item analysis was done and poor items were discarded and some others were modified. The vocabulary test contained 50 items.

(3) Since the time interval between the pre-test and post-test was long enough, the same pre-test was used as post-test too (researcher-made post-test). Based on (Hatch \& Farhady, 1982, p.22), we can use a pre-test as post-test, if there is more than two weeks duration between them. The lower-intermediate vocabulary test was conducted again as post-test at the end of the course in order to measure the progress of learner's vocabulary retention.

\section{Procedure}

At first, a Nelson test as homogenizing tool was administered to 50 lower-intermediate EFL participants. Those participants who were located one standard deviation above and below the mean were selected to participate in this study. Having analyzed the data, 40 participants were chosen for the purpose of this study. They were randomly assigned into experimental and control groups with 20 in each group. In order to select the words that were new and unfamiliar to students, a list of sixty five words were given to both groups before the treatment. Participants were required to recognize the familiar words and write down their Farsi translation. There were fifteen words that students could recognize the meanings. Consequently, fifty unknown words were selected for the purpose of this study. The source for selecting words was the book 'Thoughts and Notions: Reading and vocabulary development by Ackert \& Lee (2005).

Participants in both experimental and control groups took a pre-test. The researcher explained the project to the participants of the e-mail group, introduced the possible use of e-mail in foreign Language learning, and expressed the hope that the students would choose to participate. The participants of experimental group received step- by- step instructions on using e-mail. The control group didn't receive e-mail training. The teacher created a class e-mail list and sent new vocabulary of each lesson to participants via e-mail. The participants were told that they should make a sentence with new vocabulary as their feedback.

During 10 sessions of treatment, fifty English words followed by definitions and example sentences were given to students. In the experimental group, the researcher sent 5 new vocabularies with definitions and example sentences via e-mail three times a week. Totally, 10 e-mail messages were sent during three weeks. In the control group, the participants were given a list of five words on paper followed by definition and example sentences three times a week. Having finished the treatment ( 3 weeks, 10 sessions), students in both groups participated for the post-test. The researcher administered the pre-test as post-test to see the effects of the treatment and procedures during the study. After 
gaining the scores from the pre-test and post-test, the independent t-test was used to see whether there is a significant difference between means of pre-test and post-test of either groups or not.

\section{Data Analysis}

To answer the research question, version 16 of the Statistical Package for Social Sciences (SPSS) was utilized. Table 1 displays the descriptive statistics and reliability indices for the pre-test, post-test and Nelson test.

TABLE 1:

DESCRIPTIVE STATISTICS PRE-TEST AND POST-TEST

\begin{tabular}{|c|c|c|c|c|c|c|c|c|c|c|}
\hline & \multirow[t]{2}{*}{$\mathrm{N}$} & \multirow[t]{2}{*}{ Mean } & \multirow[t]{2}{*}{ Variance } & \multicolumn{3}{|c|}{ Skewness } & \multicolumn{3}{|l|}{ Kurtosis } & \multirow[t]{2}{*}{ K-R21 } \\
\hline & & & & statistic & Std. Error & Ratio & Statistic & Std. Error & Statistic & \\
\hline PRETETS & 40 & 15.75 & 19.628 & .455 & .374 & 1.21 & -.665 & .733 & -.911 & .87 \\
\hline POSTTTS & 40 & 34.92 & 52.533 & -.011 & .374 & .029 & .043 & .733 & .058 & .81 \\
\hline NELSON & 40 & 37.1250 & 24.856 & .177 & .374 & .473 & -.707 & .733 & .964 & .82 \\
\hline
\end{tabular}

Perhaps the most important statistics are those for the skewness and kurtosis. In order to have an almost normal distribution the ratio of the skewness and kurtosis over their respective standard errors are within the range of plus and minus 2.

As indicated in this table, mean score of homogenized test is (37.12).To examine the effects of e-mailing on vocabulary retention, a test of English proficiency including a subtest of vocabulary was developed. To obtain the desired results, reliability of pre-test and post-test were calculated. In this section the reliability of pre-test and post-test were calculated by Kuder-Richardson formula 21. The result is indicated in table 1. The result shows that Kuder-Richardson formula 21 for post-test is .81 and it can be acceptable. Since this index is large enough and it is near to one (bigger than practically accepted measure 0.65 ), we can conclude that post- test is reliable. According to table 1, reliability of pre-test is .87 .

T-test was conducted for experimental and control groups before the treatment to show the homogeneity of the two groups .An independent t-test is run to compare the means scores of the experimental and control groups on the pre-test of vocabulary. The t-observed value (.42) at 38 degrees of freedom is lower than the critical t-value, (2.02), therefore the difference between two means of groups obtained from pre-test is not statistically meaningfully, indicating the fact that two groups were similar before the start of the experiment. Table 2 provides the statistics for this analysis.

TABLE2:

INDEPENDENT T-TEST PRE-TEST OF VOCABULARY BY GROUPS

\begin{tabular}{|c|c|c|c|c|c|c|c|c|c|}
\hline & \multicolumn{2}{|c|}{$\begin{array}{l}\text { Levene's Test for } \\
\text { Equality of Variances }\end{array}$} & \multicolumn{7}{|c|}{ t-test for Equality of Means } \\
\hline & \multirow[t]{2}{*}{$\mathrm{F}$} & \multirow[t]{2}{*}{ Sig. } & \multirow[t]{2}{*}{$\mathrm{T}$} & \multirow[t]{2}{*}{ Df } & \multirow[t]{2}{*}{$\begin{array}{l}\text { Sig. } \\
\text { (2-tailed) }\end{array}$} & \multirow[t]{2}{*}{$\begin{array}{l}\text { Mean } \\
\text { Difference }\end{array}$} & \multirow[t]{2}{*}{$\begin{array}{l}\text { Std. Error } \\
\text { Difference }\end{array}$} & \multicolumn{2}{|c|}{$\begin{array}{l}\text { 95\% Confidence Interval } \\
\text { of the Difference }\end{array}$} \\
\hline & & & & & & & & Lower & Upper \\
\hline Equal variances assumed & .848 & .363 & .424 & 38 & .674 & .600 & 1.416 & -2.267 & 3.467 \\
\hline Equal variances not assumed & & & .424 & 36.759 & .674 & .600 & 1.416 & -2.270 & 3.470 \\
\hline
\end{tabular}

T-test was conducted for experimental and control groups before the treatment to show the homogeneity of two groups. Furthermore, the T-test for equality of means shows that significant value is .674 which is $>0.05$. That means there is no significant difference between the groups at the beginning of treatment and they are homogenized. In testing hypothesis, if significant level $(\propto)$ ) is smaller than 0.05 , the null hypothesis is rejected which indicates a significant difference between mean scores of the two groups; on the contrary, if $\propto \geq 0.05$, the null hypothesis is accepted that is, there is no significant difference between them.

It should be noted that the two groups are homogenous in terms of their variances on the pre-test.The Levene's test of homogeneity of variances $\mathrm{F}=.84$ has a probability of .36 . The probability associated with the Levene's $\mathrm{F}$ is much higher than the significance level (.05). That is why the first row of Table 2, "Equal variances not assumed" is reported.

Consequently, it can be claimed that the participants of the study were homogenous in their vocabulary knowledge prior to the beginning of the study. Therefore, the participants in both groups had similar status in case of vocabulary knowledge. Table 3 shows the descriptive statistics for this analysis.

TABLE 3:

\begin{tabular}{lllll}
\multicolumn{5}{c}{ TABLE 3: } \\
\multicolumn{5}{c}{ DESCRIPTIVE STATISTICS PRE-TEST OF VOCABUlary BY GROUPS } \\
\hline GROUP & $\mathrm{N}$ & Mean & Std. Deviation & Std. Error Mean \\
EXPERIMENTAL & 20 & 16.05 & 4.045 & .905 \\
CONTROL & 20 & 15.45 & 4.872 & 1.089 \\
\hline
\end{tabular}

As shown in table 3, the mean scores for the experimental and control groups are 16.05 and 15.45 respectively.

A t-test analysis performed on the means of the post-test confirmed that observed t-value of (2.81) exceeded its critical value (2.02) at 0.05 level of significance; therefore, it can be claimed that there was a significant difference between the experimental and control groups mean scores on the post-test of vocabulary after the administration of the e-mail treatment to the former group (Table4). 
TABLE 4:

INDEPENDENT T-TEST POST-TEST OF VOCABULARY BY GROUPS

\begin{tabular}{|c|c|c|c|c|c|c|c|c|c|}
\hline & \multicolumn{2}{|c|}{$\begin{array}{l}\text { Levene's Test for } \\
\text { Equality of Variances }\end{array}$} & \multicolumn{7}{|c|}{ t-test for Equality of Means } \\
\hline & \multirow[t]{2}{*}{$\mathrm{F}$} & \multirow[t]{2}{*}{ Sig. } & \multirow[t]{2}{*}{$\mathrm{T}$} & \multirow[t]{2}{*}{ Df } & \multirow[t]{2}{*}{$\begin{array}{l}\text { Sig. } \\
\text { (2-tailed) }\end{array}$} & \multirow[t]{2}{*}{$\begin{array}{l}\text { Mean } \\
\text { Difference }\end{array}$} & \multirow[t]{2}{*}{$\begin{array}{l}\text { Std. Error } \\
\text { Difference }\end{array}$} & \multicolumn{2}{|c|}{$\begin{array}{l}95 \% \text { Confidence Interval } \\
\text { of the Difference }\end{array}$} \\
\hline & & & & & & & & Lower & Upper \\
\hline Equal variances assumed & .067 & .797 & 2.817 & 38 & .008 & 5.950 & 2.112 & 1.675 & 10.225 \\
\hline Equal variances not assumed & & & 2.817 & 37.954 & .008 & 5.950 & 2.112 & 1.675 & 10.225 \\
\hline
\end{tabular}

It should be noted that the two groups were homogenous in terms of their variances on the post-test. The Levene's test of homogeneity of variances $\mathrm{F}=.06$ has a probability of .79 (Table 4) which is much higher than the significance level 0.05.So it is claimed that the two groups were homogeneous in terms of their variances. Thus it can be concluded that the null-hypothesis mentioning that "e-mail does not have any significant effect on the retention of vocabulary items" is rejected. The experimental group outperformed the control group on the post-test of vocabulary.

Consequently it is claimed that the treatment the students had in the experimental group was the cause of this significant change in the retention of vocabulary. The use of e-mail technology can enhance the retention of vocabulary among lower-intermediate Iranian learners of English. The descriptive statistics for the two groups are displayed in Table 5. The mean scores after 10 sessions of treatment for the experimental group and control group were 37.90 and 31.95 respectively. Seemingly, there is a significant difference between mean scores of the two groups. Also, the descriptive statistics show that the obtained standard deviations for the experimental and control groups are 6.56 and 6.79 respectively.

TABLE 5:

DESCRIPTIVE STATISTICS POST-TEST OF VOCABUlary By GROUPS

\begin{tabular}{lllll}
\hline GROUP & $\mathrm{N}$ & Mean & Std. Deviation & Std. Error Mean \\
EXPERIMENTAL & 20 & 37.90 & 6.561 & 1.467 \\
CONTROL & 20 & 31.95 & 6.794 & 1.519 \\
\hline
\end{tabular}

The mean scores of the pre-test in experimental group and control group were (16.05) and (15.45), respectively as shown in Table 3. The mean score of post-test in experimental group and control group were (37.90), and (31.95). The t-value of (2.817) exceeded its critical value, it can be asserted that there was a significant difference between the experimental and control groups mean scores on the post-test of vocabulary retention. These results reveal that e-mailing had a significant effect on vocabulary retention of Iranian lower-intermediate EFL learners.

\section{CONCLUSION}

The main purpose of this study was to examine the impact of e-mailing on vocabulary retention. Results indicated that the treatment the students had in the experimental group was the cause of this significant change in the retention of vocabulary. The use of e-mail technology can enhance the retention of vocabulary among lower-intermediate Iranian learners of English. The results of this study may have some hints for English teachers and Educators.EFL teachers can focus learners' attention on the use of e-mail in education. They should pay attention that e-mail can be utilized as a tool in learning vocabulary. According to the results of this study, e-mail has a positive effect on vocabulary retention. As many researchers have noted, e-mail extends what one can do in the classroom, since it provides a venue for meeting and communicating in the foreign language outside of class. Integrating the Internet in the EFL curriculum seems a logical choice, since it offers many benefits to EFL instruction itself (Rey, \& Rosado, 2001). Research in this area has pointed out many other reasons to justify the implementation of Internet based projects. There are some practical aspects that also motivate students to use e-mail. It is recommended that technology be integrated into instruction (Leh, 1999).

\section{REFERENCES}

[1] Ackert, P., \& Lee, L. (2005).Thoughts and Notions (Reading and vocabulary development). 2nd ed. Language Teaching Publications.

[2] Avila, E., \& Sadoski, M. (1996). Exploring new applications of the keyword method to acquire English vocabulary. Language Learning, 46, 379-395.

[3] Bleimann, U. (2004). Atlantis University: a new pedagogical approach beyond e-learning. Campus-wide Information. Systems, 21(5):191-195

[4] Camenson, B. (2007).Opportunities to teaching English to speakers of other languages. (Rev. ed.)New York: McGraw Hill.

[5] Cappel, J. J., \& Hayen, R. L. (2004). Evaluating e-learning: A case study. Journal of Computer Information Systems, 44 (4):49-56.

[6] Devedzic, V. (2002). What Does Current Web-Based Education Lack? Proceedings of the IASTED International Conference. APPLIED INFORMATICS, Austria, 351-607.

[7] Evans, C., \& Fan, J.P. (2002). Lifelong learning through the Virtual University. Campus-Wide Information Systems, 19(4):127-134. 
[8] Evans, J.R., \& Hasse, I.M. (2001) .Online business education in the twenty-first century: an analysis of potential target markets. Internet Research: Networking Applications and Policy, 11(3):246-260.

[9] Fowler, W.S. \& Coe , N. (1976). Nelson English Language Tests. Nelson ELT

[10] Fry, K. (2000). Forum focus and Overview. The business of E-learning: Bringing your organization in the knowledge Economy. Telcam Group, University of Technology, Sydney.

[11] Grace, C. (1998). Retention of word meanings inferred from context and sentence-level translation: implications for the design of beginning-level CALL software. The Modern Language Journal 82, 533-544.

[12] Groot, P. J. M. (2000).Computer assisted second language vocabulary acquisition. Language Learning \& Technology,4: 60-81.

[13] Hambrecht, W. \& Company. (2000). Corporate E-learning: Exploring a new frontier, Special E-Learning Section, Forbes, summer, 2000.

[14] Hamid, A.A. (2002).e-Learning-Is it the "e" or the learning that matters. Internet and Higher Education, 4: 311-316.

[15] Hamilton, R., Richards, C., \& Sharp, C. (2001). An examination of e-learning and e-books. Retrieved December 12, 2003,from www.dcs.napier.ac.uk/ mm/socbytes/jun2001/Jun2001_9.htm

[16] Hatch, E. \& Brown, C. (2000). Vocabulary, Semantics, and Language Education (3rd printing). Cambridge: Cambridge University Press.

[17] Hatch, E., \& Farhady, H. (1982). Research design and statistics for applied linguistics. Tehran: Rahnama Publications.

[18] Honey, P. (2001). E-learning: a performance appraisal and some suggestions for improvement. The Learning Organization, $8(5): 200-202$.

[19] Horton, W. (2001). Leading e-Learning. American Society for Training and Development, Retrieved April 25, 2003, from http://www.elearninggurus. om/articles.html

[20] Hunt, A., \& Beglar, D. (2005). A framework for developing EFL reading vocabulary. Reading in a Foreign Language,17(1): 24-59.Available online at http://nflrc.hawaii.edu/rfl

[21] Lahn, L.L. (2004). Dilemmas in the development of e-learning at work. Journal of Workplace Learning, 16(8): 466-478.

[22] Laufer, B., \& Hulstijn, J. (2001). Incidental vocabulary acquisition in a second language: the construct of task-induced involvement. Applied Linguistics, 22: 1-26.

[23] Leh, A. (1999). Computer-Mediated communication and foreign Language learning via electronic mail. Interactive Multimedia Electronic Journal of Computer Enhanced Learning, 1 (2) from http://imej.wfu.edu/articles/1999/2/08/printver.asp

[24] Lewis, M. (1993). The Lexical Approach: The state of ELT and the way forward. Hove, England: Language Teaching Publications.

[25] Lindh, J., \& Soames, C. A. (2004). A dual perspective on an online university course. Electronic Journal on e-Learning, 2 (1): 129-134.

[26] Lytras, M.D., Pouloudi, A., \&Poulymenakou, A. (2002). Knowledge management convergence: Expanding learning frontiers. Journal of Knowledge Management, 6(1): 40-51.

[27] Maynard, S. \& Cheyne, E. (2005). "Can electronic textbooks help children to learn?", Electronic Library, 23 (1):103 - 115

[28] Nagel, P. S. (1999). E-mail in the virtual ESL/EFL classroom. The internet TESL Journal, 5 (7). Available online at iteslj.org/Articles/Nagel-Email.html

[29] Rey, L., \& Rosado, N. (2001). Empowering the EFL/ESL class through e-mail activities. Available online at http://manglar.uninorte.edu.co/handle/10584/390

[30] Roffe, I. (2002). E-learning: Engagement, enhancement and execution. Quality Assurance in Education, 10(1):40-50.

[31] Sambrook, S. (2003). E-learning in Small Organizations. Education + Training, 45(8 /9): 506-516.

[32] Schank, R.C. (2002). Designing world class E-Learning. 1st ed., McGraw Hill, USA.

[33] Schmitt, N. (1997). Vocabulary Learning Strategies. In N. schmitt and M. Mccarthy (Eds.), vocabulary: Description, Acquisition and pedagogy, (pp.199-227).Cambridge: Cambridge University Press.

[34] Tsai, S., \& Machado, P. (2002). E-learning, On-line Learning, Web-based Learning, or Distance learning: Unveiling the Ambiguity in Current Terminology. E-Learn Magazine, Association of Computing Machinery, Retrieved April 25, 2003, from http://www.elearnmag.org/subpage/sub_page.cfm?section=3 \&list_item=6\&page=1

[35] Wikipedia. (2010).Email. Retrieved December 2, 2010, from http://en.wikipedia.org/wiki/Email

[36] Wild, R.H., Griggs, K. A., \& Downing, T. (2002).A framework for e-learning as a tool for knowledge management. Industrial Management \& Data Systems, 102(7): 371-380.

[37] Wilson, R. (2003).E-education in the UK. Journal of Digital Information, 3 (4):7.

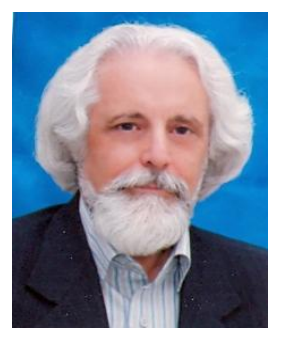

Mansoor Fahim was born in Iran in 1946. He received a Ph.D. in TEFL (Teaching English as a Foreign Language) from Islamic Azad University in Tehran, Iran in 1994, an M.A. in General Linguistics from Tehran University in Tehran, Iran in 1978, and a B.A. in English Translation from Allameh Tabataba" $i$ University in Tehran, Iran in 1975.

As for his professional background, he was the chairman of the EFL department at Allameh Tabataba" $i$ University from 2003 to 2007 and a member of the faculty of English Language and Literature at Allameh Tabataba" $i$ University in Tehran, Iran from 1979 to 2008 when he was retired as an associate professor of TEFL. He has also taught English at a welter of universities and language schools. At present, he runs Psycholinguistics, Applied Linguistics, First and Second Language Acquisition, and Discourse Analysis courses at M.A. and Ph.D. levels at a number of universities in Iran, including Allameh Tabataba"i and Islamic Azad Universities. Moreover, he has several published articles and books mostly in the field of TEFL including: (1) Fahim, M. \& Nezakatgoo, B. (2006) GRE general words for graduate and post-graduate students. Tehran: Rahnama Publications. (2) Ghobadi, A. \& Fahim, M. (2009). The effect of explicit teaching of English ,thanking formulas" on Iranian EFL intermediate level students at English language 
institutes', System: 526-537. (3) Fahim. M., Bagherkazemi, M. \& Alemi, M. (2010). The relationship between test takers" multiple intelligences and their performance on the reading sections of TOEFL and IELTS.BRAIN. Broad Research in Artificial Intelligence and Neuroscience, 1 (3) : 27-41.

Dr. Mansoor Fahim is currently a member of the editorial board of the Iranian journal of Applied Linguistic Studies, Sistan \& Baloochestan University, Iran; Journal of Language Studies, Shahrekord University, Iran; and Journal of English Language Studies, Islamic Azad University, Tehran, Iran.

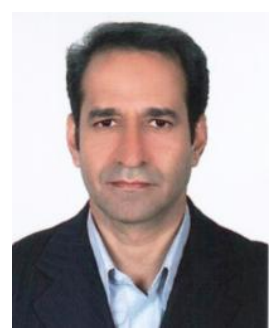

Khalil Motallebzadeh is assistant professor at the Islamic Azad University (IAU) of Torbat-e-Heidarieh and Branch, Iran. He is a widely published established researcher in language testing and e-learning. He has been a visiting scholar at the University of Illinois at Urbana Champaign (UIUC) in 2007-2008. He is also an accredited teacher trainer of the British Council since 2008 and is currently the Iran representative of Asia TEFL.

Zeinab Sazegar received her MA in TEFL from Islamic Azad University, Garmsar Branch, Iran in 2011. She is interested in e-learning and teaching methodology. 